\title{
Research on Chengdu Vegetables Marketing Based on STP Model
}

\author{
Qiang $\mathrm{Liu}^{1,2} \&$ Xiumin $\mathrm{Wu}^{1}$ \\ ${ }^{1}$ College of Economics \& Management, Sichuan Agricultural University, Chengdu, China \\ ${ }^{2}$ Chengdu University of Information Technology, Chengdu, China \\ Correspondence: Qiang Liu, College of Economics \& Management, Sichuan Agricultural University, Chengdu \\ 611130, China. Tel: 86-130-9448-8468. E-mail: 511936607@qq.com
}

Received: January 22, 2013 Accepted: February 11, 2013 Online Published: March 28, 2013

doi:10.5539/ass.v9n4p221 URL: http://dx.doi.org/10.5539/ass.v9n4p221

\begin{abstract}
In this paper, we take the consumers in Chengdu vegetables market as samples, in the form of questionnaires and interviews, to study the consumer motivations and psychology, and make market segmentation of consumers. Results show that the consumers in Chengdu vegetables market can be divided into four types: the safety-pursuing type, the convenient and economical type, the family healthy type, and the fashionable type, among which the safety-pursuing type is the largest. Finally, authors put forward some suggestions for Chengdu vegetables market based on current conditions.
\end{abstract}

Keywords: vegetable, STP model, Chengdu

\section{Introduction}

With the acceleration of urbanization, people have higher requirements for quality of life. People's needs for vegetables are not only about the quantity, but more focus on the quality. The quality of vegetables refers to the attributes of agricultural products satisfying consumers' needs, i.e. the use value of agricultural products (Yukang \& Kangpin, 1999). Whether the quality of agricultural products is good or bad is determined by the degree of satisfying consumers' needs, judging from the nutrition, the safety, and the taste (Ming, 2003).Because of different education levels, family incomes, and life values, the supply of vegetables should adapt to different groups of consumers in order to satisfy the diversified needs of the market. Therefore, by means of market segmenting, we can integrate the consumers with same or similar needs together and form different segment markets, providing the information of consumer needs in different sub-markets for vegetables marketers, and helping them develop effective vegetables marketing strategies for different segment markets (Xueyu \& Shiping, 2012). Identifying the relevant factors that affect consumers' consumption behaviors is the key for market segmentation. The consumption behaviors of consumers are mainly under the influences of four kinds of elements, i.e. cultures, societies, individuals, and psychologies. According to Kolter, the psychological element directly affects the consumption behaviors of consumers, among which the motive is the primary variable that influences the consumption behaviors of consumers (Kotler, 1999). Therefore, in this sense, choosing the consumption motive as the standard for segmenting vegetables market is very reasonable and effective.

However, the consumer segmentation and differentiation are imperfect in Chengdu vegetables market, which not only affects the diversified needs of consumers, but also hinders the maturity of Chengdu vegetables market. Therefore, by means of questionnaires and interviews, authors get to know consumers' motives for and habits of buying vegetables, examine consumers' acceptance to medium, low, and high-end vegetables, explore the unsatisfied needs, and propose specific methods to implement the STP marketing strategy.

\section{Model Selection and Data Sources}

\subsection{STP Model}

The STP model is the core of modern strategic marketing, which is firstly proposed by the American marketing expert Wendell Smith in 1956 and then improved further by Philip Kotler. Here, S is an abbreviation of the word "Segmenting", which means market segmentation, i.e. dividing a broad target market into subsets of consumers who have different needs, characteristics, or behaviors, as well as needs for different products or marketing programs (Gary \& Philip, 2010). T is an abbreviation of the word "Targeting", which means target market, i.e. after segmenting the market, analyze and choose the most profitable market segment for enterprise business as 
the object to carry out marketing activities (Zhiwei, Hang \& Zhenlai, 2009). P is an abbreviation of the word "positioning", which means market position, i.e. considering the importance of certain attribute of the product to the consumers, convey the attribute of the product to the consumers effectively by a series of marketing activities, and establish the proper position of the product in market (Ling, 2008).

At present, the application of STP model in economic field is very broad. Qi Zhao and Jiannan Guo (1994) adopted the STP marketing strategy and discussed the development of close brands for senior citizens. Tong Pan (2005) applied the STP model to the planning of real estate marketing. Xiaoguang Ji et al. (2012) and Shangwu Liu et al. (2012) applied the STP model respectively to the stone export and the fruit import. Generally speaking, the STP model is conductive to understand the characteristics of various market segments and develop and adjust the combined marketing strategies. Therefore, in this paper authors use the STP model to study Chengdu vegetables market. The market segmentation is mainly based on consumers' purchasing motive, consumption habits, etc. Then, select the largest subset of consumers as the target market of STP marketing strategy. At last, authors put forward relevant marketing strategies.

\subsection{Data Sources}

In order to acquire necessary data, we use both group discussions and questionnaires to achieve the unity of quality and quantity.

We organize three groups for interviews, each with 6-8 people. Conditions for samples are married women aged from 25 to 60 years old, no specific requirements for work types. Choosing the married women aged from 25 to 60 years old as the samples is determined by the family components of China. Married women are the decision-makers for the purchase of family food. Three groups are G1: 25-35 years old; G2: 36-45 years old; G3: 46-60 years old, which provides sufficient explanations for the results of analyses. As for the questionnaire survey, we collect samples randomly at the street and finally get 400 samples. The survey covers the five regions of Chengdu and each region contributes the same size of samples. The questionnaire generally costs $20-25$ minutes.

\section{Analysis of results}

\subsection{Sample Description}

The survey includes 400 consumers. From the angle of ages, the ages of most samples are between 25 and 45 years old, accounting for $49.5 \%$ of the overall samples. $35.5 \%$ of samples are at the ages between 46 and 55 years old, and $15 \%$ of samples are at the ages between 56 and 60 year old. From the angle of education, $5.2 \%$ of samples, namely 21 consumers, are at the level of primary school. $10.8 \%$ of samples, namely 43 consumers, are at level of junior high school. $26.2 \%$ of samples, namely 105 consumers, are at the level of senior high school. $51.6 \%$ of samples, namely 206 consumers, are at the level of college. $6.2 \%$ of samples, namely 25 consumers, are at the level of postgraduate. From the angle of job specification, most interviewees are from public sectors or enterprises. The percentages are respectively $14.8 \%$ and $56.4 \%$. Percentages of housewives, retired women, and civil servants are respectively $8.1 \%, 9.1 \%$, and $5 \%$. From the angle of family income conditions, the monthly family income of most interviewees is below 6,000 Yuan, accounting for $63.8 \%$ of the total samples. $33.2 \%$ of interviewees have the monthly family income from 6,000 Yuan to 10,000 Yuan. Only $3 \%$ of interviewees have more than 10,000 Yuan monthly family income.

\subsection{Market Segmentation}

In this paper, we apply the fast clustering analysis method to segment Chengdu vegetables market and use the 5-point Likert scale to measure the motives of consumptions. 1 stands for "extremely unimportant", 3 for "common", and 5 for "extremely important". Results show that Chengdu vegetables market can be divided into four segment markets, i.e. the safety-pursuing type, the convenient and economical type, the family healthy type, and the fashionable type. Details are displayed in Table 1. 
Table 1. The segmentation of Chengdu vegetables market

\begin{tabular}{|c|c|c|c|c|c|c|}
\hline Type of market & Mean & $\begin{array}{l}\text { Standard } \\
\text { deviation }\end{array}$ & Communalities & $\begin{array}{l}\text { Factor } \\
\text { loading }\end{array}$ & $\begin{array}{l}\text { Eigen } \\
\text { value }\end{array}$ & $\begin{array}{l}\text { Variance } \\
\text { contribution (\%) }\end{array}$ \\
\hline \multicolumn{7}{|l|}{ Safety-pursuing type } \\
\hline Additive-free & 3.75 & 0.867 & 0.600 & 0.767 & & \\
\hline $\begin{array}{l}\text { No artificial } \\
\text { ingredients }\end{array}$ & 3.67 & 0.953 & 0.708 & 0.761 & & \\
\hline Natural & 3. 42 & 1.021 & 0.500 & 0.732 & 6.305 & 31.52 \\
\hline Residual-free & 3. 60 & 0.918 & 0.654 & 0.658 & & \\
\hline Safer & 3. 86 & 0.806 & 0.523 & 0.606 & & \\
\hline Environment friendly & 3. 65 & 0.795 & 0.585 & 0.516 & & \\
\hline \multicolumn{7}{|l|}{ Family healthy type } \\
\hline More trace elements & 3.57 & 0.840 & 0.650 & 0.755 & & \\
\hline Rich nutrition & 3. 88 & 0.792 & 0.609 & 0.723 & & \\
\hline High protein & 3. 58 & 0.901 & 0.587 & 0.700 & 1.891 & 9.455 \\
\hline Low sterol & 3.30 & 0.881 & 0.561 & 0.645 & & \\
\hline Family healthy & 3.75 & 0.836 & 0.557 & 0.642 & & \\
\hline Weight control & 2. 98 & 0.923 & 0.530 & 0.508 & & \\
\hline \multicolumn{7}{|l|}{ Fashionable type } \\
\hline Attractive color & 3. 19 & 0.961 & 0.693 & 0.816 & & \\
\hline Beautiful shape & 2. 96 & 1. 036 & 0.524 & 0.811 & 1.524 & 7. 620 \\
\hline Consumption fashion & 3.44 & 0.949 & 0.704 & 0.644 & & \\
\hline Eating habit & 3.44 & 0.987 & 0.409 & 0.453 & & \\
\hline $\begin{array}{ll}\text { Convenient } & \text { and } \\
\text { economical type }\end{array}$ & & & & & & \\
\hline Economy of prices & 4. 04 & 0.871 & 0.717 & 0.834 & 1. 381 & 6.905 \\
\hline $\begin{array}{l}\text { Convenient shopping } \\
\text { site }\end{array}$ & 3. 70 & 1. 012 & 0.716 & 0.790 & & \\
\hline $\begin{array}{l}\text { Quality assurance } \\
\text { factor }\end{array}$ & & & & & & \\
\hline Reliable package & 3.15 & 1.037 & 0.671 & 0.702 & 1.021 & 5.106 \\
\hline Quality certificate & 3.51 & 0.915 & 0.645 & 0.611 & & \\
\hline
\end{tabular}

The safety-pursuing consumers take the safety of vegetables as the primary factor to make the purchase decision. They mainly focus on the quality and the safety of vegetables. This type of consumers is usually attracted by these attributes of vegetables. The family healthy-pursuing consumers care about the nutrition of vegetables and whether certain vegetables are good for the family. This type of consumers is easy to be driven by this factor in practice. As for the convenient and economical consumers, the price of vegetables is the primary element in consideration. This type of consumers usually pays more attention to the price of vegetables, prefers to "shopping around", and tends to shop near their houses. The fashion-pursuing consumers love to seek for the fashionable foods and dare to try novel foods, due to their eating habits and special life values.

\subsection{Target Market}

Make statistical analysis based on data of the survey in segment markets and get the descriptions of each segment markets as follow in Table 2 . 
Table 2. The characteristics descriptions of segment markets

\begin{tabular}{|c|c|c|c|c|c|}
\hline & $\begin{array}{l}\text { Characteristics of } \\
\text { consumers }\end{array}$ & $\begin{array}{l}\text { Samples for the } \\
\text { safety-pursuing } \\
\text { type }\end{array}$ & $\begin{array}{l}\text { Samples for } \\
\text { the family } \\
\text { healthy type }\end{array}$ & $\begin{array}{l}\text { Samples for the } \\
\text { convenient and } \\
\text { economical type }\end{array}$ & $\begin{array}{l}\text { Samples for the } \\
\text { fashionable } \\
\text { type }\end{array}$ \\
\hline \multirow[t]{3}{*}{ Age } & $25-35$ & 70 & 20 & 2 & 8 \\
\hline & $36-45$ & 47 & 42 & 6 & 2 \\
\hline & $46-60$ & 67 & 66 & 68 & 1 \\
\hline \multirow[t]{5}{*}{ Education } & Primary school & 3 & 6 & 12 & 0 \\
\hline & $\begin{array}{l}\text { Junior } \\
\text { school }\end{array}$ & 10 & 11 & 21 & 1 \\
\hline & $\begin{array}{l}\text { Senior high } \\
\text { school }\end{array}$ & 31 & 33 & 40 & 1 \\
\hline & College & 108 & 79 & 12 & 7 \\
\hline & Undergraduate & 15 & 5 & 2 & 3 \\
\hline \multirow[t]{5}{*}{ Vocation } & Public institution & 32 & 25 & 14 & 3 \\
\hline & Corporate worker & 126 & 78 & 16 & 6 \\
\hline & Retiree & 9 & 12 & 14 & 2 \\
\hline & Housewife & 9 & 13 & 10 & 1 \\
\hline & Others & 3 & 5 & 12 & 0 \\
\hline \multirow[t]{3}{*}{$\begin{array}{l}\text { Monthly } \\
\text { income }\end{array}$} & $\begin{array}{l}\text { Less than } 6,000 \\
\text { Yuan }\end{array}$ & 112 & 74 & 69 & 0 \\
\hline & $\begin{array}{l}6,000-10,000 \\
\text { Yuan }\end{array}$ & 67 & 50 & 7 & 9 \\
\hline & $\begin{array}{l}\text { 10,000Yuan } \\
\text { above }\end{array}$ & 5 & 4 & 0 & 3 \\
\hline \multirow{5}{*}{$\begin{array}{l}\text { Purchasing } \\
\text { site }\end{array}$} & Specialty store & 67 & 19 & 3 & 8 \\
\hline & Famers market & 42 & 33 & 52 & 0 \\
\hline & Vegetable base & 20 & 7 & 2 & 2 \\
\hline & Supermarket & 55 & 60 & 18 & 1 \\
\hline & Others & 10 & 9 & 1 & 1 \\
\hline
\end{tabular}

According to data in Table 2, the characteristics of the safety-pursuing consumers are: mostly at the age between 25 and 35 years old and between 46 and 60 years old; mostly with college education; mostly corporate employees; less than 6,000 Yuan monthly family income; purchasing vegetables at specialty store and supermarket. The characteristics of the family healthy-pursuing consumers are: mostly at the age between 36 and 60 years old; mostly with junior or senior high school education; about 6,000 Yuan monthly family income; mostly buying vegetables at supermarket. The characteristics of the convenient and economical consumers are: mostly at the age between 46 and 60 years old; with senior high school education; more retirees and housewives; mainly buying vegetables at farmers market. The characteristics of fashionable consumers are: mostly at the age between 25 and 35 years old; monthly family income around 6,000 and 10,000 Yuan; with high educational level.

Therefore, we can conclude that the safety-pursuing consumers are mostly young employees in enterprises. As the main working force of the city, they are highly educated and have personal requirements and standards for life quality. They emphasize on the quality and the safety of vegetables. The family healthy-pursuing consumers are mostly in the middle age, as the good wives in families. They have stable career bases and economic returns. Meanwhile, they are responsible for looking after the growing children and the aging parents. Therefore, as they buy vegetables, they usually make decisions on whether the vegetables are healthy or not. The convenient and 
economical consumers are mostly aged retirees and housewives. They have more spare time and are more sensitive to the price of vegetables. They usually shop around. However, because of the ages and physical healthy, they usually purchase vegetables near their living houses. Besides, because they are economical, they prefer to buying vegetables in the farmers market nearby. The fashionable consumers are mostly young and highly educated, with high income. They are advancing and pursuing for fashion. They have special preferences and requirements for the selection of vegetables.

Generally speaking, as for consumers who pursue for the safe, healthy, and fashionable nature of vegetables, there is an increasing trend that these consumers have high educational levels and more incomes, younger, and purchasing by specialized channels. Peoples' requirements for vegetables, except for the healthy nature of vegetables, are more focusing on the safety of vegetables. People's pursuits for the fashionable nature of vegetables also show certain potentials. Among the 400 consumers in the survey, 184 consumers belong to the safety-pursuing type, accounting for $46 \%$ of the total sample; 128 consumers are the family healthy-pursuing type, accounting for $32 \%$ of the total sample; 76 consumers are the convenient and economical type, accounting for $19 \%$ of the total sample; only 12 consumers are the fashionable type, accounting for $3 \%$ of the total sample. See Figure 1 for details.

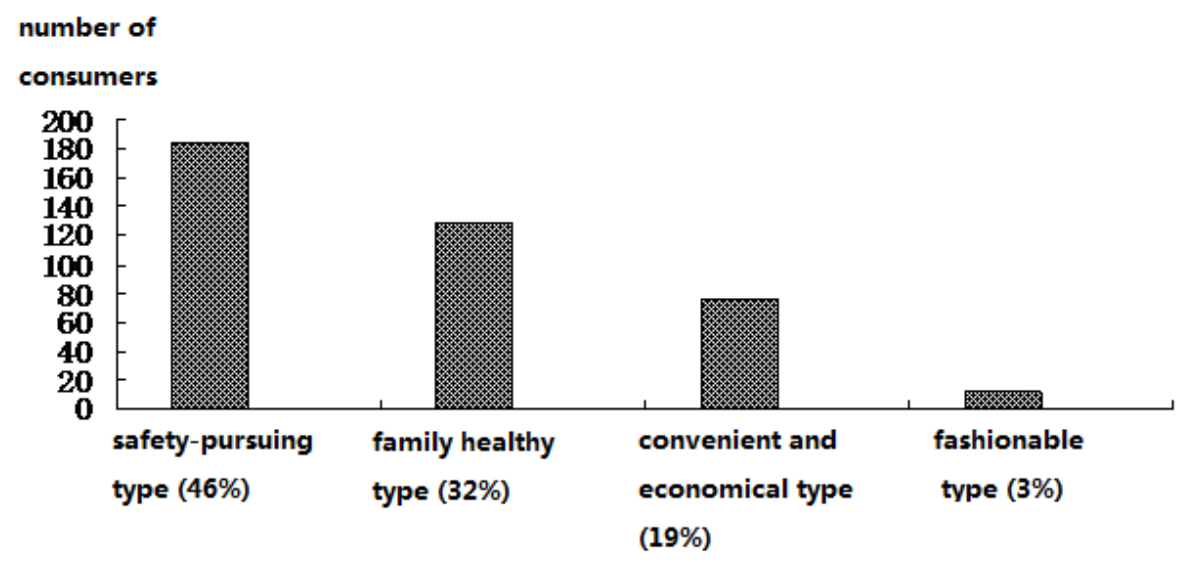

Figure 1. The histogram of the segmentation of Chengdu vegetables market

The safety-pursuing consumers regard the safety of vegetables as the primary element in consideration. They make decisions based on the quality and the safety of vegetables. Reasons for this fact include two aspects. On one hand, the consumers' awareness of safe food is improving. On the other hand, people have better economic returns and they prefer to qualified, safe, and fashionable things. The proportion of the safety-pursuing consumers is the largest in the segment markets in this paper. Therefore, we select this kind of consumers as the target market to make further study.

\section{Conclusions and Suggestions}

In this paper, in perspective of consumption motives and consumption habits, we segment Chengdu vegetables market and divide the market into four sub-markets: the safety-pursuing market, the family healthy-pursuing market, the convenient and economical market, and the fashionable market. Here, the safety-pursuing market is the largest sub-market, in which the consumers account for $46 \%$ of total consumers in Chengdu vegetable market.

In perspective of marketing, the safety-pursuing consumers are mostly young and accept higher education. This type of consumers concerns about the expected elements of certain product. They desire for the safer and highly-qualified elements of the product, besides the common attributes of the product. Therefore, we can take efforts in these following aspects.

4.1 Further Improve the Vegetable Growers' Awareness of Safety and Quality and Enhance the Quality of Vegetable Growers

Vegetable growers' awareness of quality of vegetables is directly related to the quality and safety of vegetables in market. Therefore, we should popularize the knowledge of safe and qualified vegetables among vegetable growers by means of TV, radio, and Internet. Meanwhile, we can provide technological assistances for the countryside, carry out guidance and training activities, and promote the standardized vegetables growing 
technologies and the equipped technologies for growing pollution- free vegetables.

\subsection{Improve the Vegetables Quality Standard System and Promote the Implementation}

Learn from international advanced experiences and achievements, accelerate to establish the local vegetables safety standards, and form the reasonable vegetables standard system. At the same time, strengthen the promotion of standardized production of vegetables, encourage enterprises and professional cooperatives to become the main forces of implementing the standard production of vegetables, promote the vegetables industry to transfer from extensive to intensive operation, and improve the application of proper advanced technologies and standard production technologies.

\subsection{Enhance the Enforcement of Agricultural Laws and Strictly Control the Use of Inputs in Production of Vegetables}

Enhance the monitoring of pesticide residues in vegetables growing bases and strictly control the agricultural inputs. Make unscheduled inspections and establish severe punishment. Provide more training for the retailers of agricultural materials and examine the flow of agricultural inputs resolutely. Reduce the use of chemical pesticides and improve the quality of vegetables and the safety of foods. Use nitrogen fertilizer reasonably and adopt the soil testing and fertilizer technology, reducing the environmental pollution and waste of fertilizers.

\subsection{Improve the Vegetables Market System and Promote the Circulation of Common Signals}

Improve the wholesale market and the retail channels for vegetables and regulate the market strictly. Rank the vegetables in market according to the level of quality and mark the vegetables with relevant signals. By this way, we can gradually change the traditional way of selling vegetables, i.e. "collect and distribute vegetables, no signals, and no packages", and form the modern community market for vegetables. By giving vegetables signals and commitments, we can help to form the price mechanism of qualified and safe vegetables, achieving the traceability of the quality and safety of vegetables.

\subsection{Create the New Production-Marketing System for Vegetables}

Promote the industrial business mode of "company + farmers", "company + cooperative + farmers", etc. and make the leading company play the exemplary role in practice. Encourage companies to develop the "on-order agriculture" and build the "interests-sharing and risks-sharing" mechanism with farmers. Establish the new production-marketing system for vegetables by means of building bases, connecting with markets, ordering, developing brands, and distributing. Food safety has the characteristics of credence goods (Nelson, 1970). Producers and retailers can improve the degree of organized production and marketing and establish the mutual trust mechanism between the supply and the demand by long-term cooperation so that they can attract more consumers to buy safe vegetables.

\section{References}

Armstrong, G., \& Kotler, P. (2010). Marketing: An Introduction (9th ed.). Translated by Yilin Lv. Beijing: China Renmin University Press. http://dx.doi.org/10.1111/j.1471-0307.1970.tb01100.x.

Helian, Z. W., Li, H., \& You, Z. L. (2009). Marketing. Beijing: China Machine Press.

Ji, X. G., \& Sun, M. H. (2012). An analysis of STP marketing strategy of stone export products - A case study of Hebei HG Trading Co., Ltd. Journal of Hebei North University, 4, 60-70.

Kotler, P. (1999). Marketing Management: Analyzing, Planning, Executing, and Control. Shanghai: Shanghai Renmin Publishing House.

Lan, L. (2008). Marketing. Beijing: China Machine Press.

Nelson, P. (1970). Information and consumer behavior. Journal of Political Economy, 78, 311-329. http://dx.doi.org/10.1086/259630

Tang, X. Y., \& Li, S. P. (2012). Research on market segmentation of safe agricultural product from the dimension of consumer motive - A case study of Nanjing. Journal of Agro-Technological Economics, 1, 109-117.

Weng, M. (2003). Quality of Chinese agricultural products and international competitiveness. Chinese Rural Economy, 4, 20-26.

Yao, Y. K., \& Ma, K. P. (1999). Research on the market competition of agricultural products. Chinese Rural Economy, 11, 43-47.

Zhao, Q., \& Guo, J. N. (1994). The STP model for real estate marketing planning. Journal of Panyu Polytech, 4, 27-30. 